\title{
Regionalisation of the Republic of Slovenia
}

\author{
UDK: 353(497.4) \\ Stane Vlaj \\ Univerza v Ljubljani, Fakulteta za upravo \\ stane.vlaj@fu.uni-lj.si
}

\begin{abstract}
The paper critically examines the planned introduction of fourteen regions in the Republic of Slovenia (RS). Regions as a mandatory second level of selfgovernment will be of major importance for the decentralisation of Slovenia, and consequently for the implementation of the principle of subsidiarity as the fundamental principle in arranging relations between the State and sub-national government levels. However, there are some serious disagreements about the size, competences and financing of the regions.

An appropriate division of the state territory into regions is the basis for the optimal territorial organisation of material activities as well as for the settlement of population and decentralisation of state functions. Numerous economic, administrative, geographical and other reasons justify the need to divide Slovenia into regions, preferably into six to eight regions.

The paper confronts this project with international criteria and standards as well as with some cases of regionalisation in the European Union (EU) and in the Council of Europe (CE) member states. The author recognises that in almost all CE member states, far-reaching reforms of regional authorities have been completed, are in progress or are planned for the years ahead. The CE, preparing a document (recommendation/convention) on regional self-government, respects the sovereignity and freedom of member states to determine their own internal organisation in conformity with the fundamental standards and principles of democracy. The CE also considers that the process of decentralisation and the regional authorities where they exist can facilitate economic growth, sustainable development, quality public services and the strengthening of democracy.
\end{abstract}

Key words: regionalisation, region, regional self-government, devolution, subsidiarity principle, decentralisation, good governance.

\section{Introduction}

The main goal of the establishment of regions in Slovenia is efficient management with the aim to ensure quality services for the local and regional population. It involves includingthe new unit of territorial self-government (democracy) in the substantive issues, especially that of sound management, which will benefit the local population. 


\section{Stane Vlaj \\ Regionalisation of the Republic of Slovenia}

When constitutional changes ${ }^{1}$ to ensure a constitutional basis for the implementation of regions as a mandatory second level of local self-government were adopted in June 2006, a sufficiently high consensus in favour of the changes was reached among political parties. This, however, is no longer true as far as the preparation and passing of "regional " legislature is concerned, which would be necessary for regions to come into existence. Complications have arisen regarding nearly every issue - the number of regions, their competences and financing, the seats of regional authorities and agencies, the names of regions, their relations to municipalities, and so on. We can see that this is very similar to how the establishment of new municipalities played out. In the worst-case scenario, the implementation of regions will simply not happen in this term of office, which endns in the autumn of this year. From the point of view of achieving the goals of local self-government, which in the majority of European countries exists on two levels, this would be a setback.

The processes of regionalisation are taking place all over Europe, both in countries with a long tradition of local self-government (Germany, England, France etc) and in new democracies (the Czech Republic, Poland, Slovakia etc). There exist common challenges as well as circumstances specific to every country. ${ }^{2}$ Constitutions are being changed, new legal frameworks are being adopted, the principle of subsidiarity - which strengthens the position of local and regional communities - is being implemented, new financial arrangements between the state and sub-state levels of authority are being developed, institutional dialogue between all levels and branches of governance is growing, the participation of citizens in local and regional democracy is being fostered above all, emphasis is being put on good governance of local and regional communities.

The main organisation concerned with local and regional democracy at a European level is the $C E$, which has been increasingly successful at harmonising its activities in the area with those of the EU. Democracy is at the heart of activity in the $\mathrm{CE}$, and local and regional democracy is integral to it. In modern Europe, no country can really declare itself to be democratic if it has not formed local self-government based on free elections, and if it has not made government responsible to the citizens. The implementation of the principle of

1 Constitutional law on changes in Articles 121, 140 and 143 of the Constitution of the Republic of Slovenia (UZ121, 140, 143), Official Gazette. RS, No. 68/2006.

2 The creation of a regional level is underway or under consideration in several countries Slovenia, Hungary, Romania, Latvia. 


\section{Regionalisation of the Republic of Slovenia}

subsidiarity and good governance on all levels, which are crucial to the $C E$, are linked to this, of course. ${ }^{\mathbf{3}}$

At the 14th Conference of CE member states' ministers responsible for local and regional self-government, which took place in October 2007 in Valencia, Spain, an extensive Declaration ${ }^{\mathbf{4}}$ dealing with the most important questions of local and regional democracy was adopted. Particular attention was paid to the European experiences, developments, and innovations in regional self-government in recent years. As they did at a conference in February 2005 in Budapest, the ministers once more stressed the importance of regional selfgovernment as an enrichment of democratic society, as a method of meeting the challenges faced by democratic administration, and as a way of dealing with public issues at a level as close as possible to the citizens. ${ }^{\mathbf{5}}$

\section{Different models of local (regional) self- government in Europe}

In Europe, local self-government has a severalcentury-long tradition comprising variegated regimes. The models of local self-government vary in volume, structure, tasks, and their relations to the state. Their common feature is that they each rest on their own tradition and historical development. Different models of local self-government will continue to exist in the future, for there does not and cannot exist a single model, not even within individual (federal) states. The European Charter on Local Self-Government (ECLS) and other documents of the $\mathrm{CE}$ and the EU relating to local and regional communities respect the diversity of those models.

In almost all CE member states, far-reaching reforms of regional authorities have been completed, are in progress or are planned for the years ahead. These reforms involve federal states, highly decentralised states with a

3 European Committee on Local and Regional Democracy (CDLR), Report of the CDLR to the Committee of Ministers, (117th Session, 10-11 May 2007), Strasbourg, 12 March 2007, p. 2.

4 Conference of European ministers responsible for local and regional government, Valencia Declaration, Council of Europe, MCL-15(2007)5 final, 16 October 2007.

5 European Committee on Local and Regional Democracy (CDLR), Proposals for the further work on regional self-government following the "cluster-approach" (thematic groups), Strasbourg, 16 November 2007, p. 2. 
Stane Vlaj

\section{Regionalisation of the Republic of Slovenia}

considerable degree of regional self-government, decentralised states and states in the process of regionalising their systems of government. ${ }^{6}$

Table 1: Models of local (regional) self-government in Europe

\begin{tabular}{|c|c|c|c|}
\hline & $1^{\text {st }}$ tier & $2^{\text {nd }}$ tier & $3^{\text {nd }}$ tier \\
\hline \multicolumn{4}{|c|}{ Federal states } \\
\hline Austria & 2357 & 9 & \\
\hline Belgium & 589 & 10 & 6 \\
\hline Germany & 12312 & 323 & 16 \\
\hline \multicolumn{4}{|c|}{ Unitary states } \\
\hline Bulgaria & 264 & & \\
\hline Cyprus $^{7}$ & 524 & & \\
\hline Czech Republic & 6249 & 14 & \\
\hline Denmark & 98 & 5 & \\
\hline Estonia & 227 & & \\
\hline Finland & 416 & & \\
\hline France $^{8}$ & 36683 & 100 & 26 \\
\hline Greece & 1034 & 50 & \\
\hline Hungary & 3175 & 19 & \\
\hline Ireland & 114 & 8 & \\
\hline Italy & 8101 & 103 & 20 \\
\hline Latvia & 527 & 26 & \\
\hline Lithuania & 60 & & \\
\hline Luxembourg & 116 & & \\
\hline Malta & 68 & & \\
\hline Netherlands & 443 & 12 & \\
\hline Poland & 2478 & 314 & 16 \\
\hline Portugal $^{9}$ & 308 & 2 & \\
\hline Romania & 3173 & 42 & \\
\hline Slovakia & $2891^{10}$ & 8 & \\
\hline Slovenia & 210 & & \\
\hline Spain & 8111 & 50 & 17 \\
\hline Sweden & 290 & 20 & \\
\hline United Kingdom & 434 & 35 & 3 \\
\hline TOTAL EU 27 & 91252 & 1150 & 104 \\
\hline
\end{tabular}

6 All states strive to achieve the size of local and regional communities with the necessary financial and human resources to provide quality public services and to meet the modern needs of the citizens. The importance of the territory is obvious from the economic, social, political or administrative point of view.

7 Including 146 authorities in the Northern part of Cyprus

8 Including overseas departments and regions

9 Portugal and the United Kingdom also have an infra-municipal level

10 Excluding districts. 


\section{Regionalisation of the Republic of Slovenia}

It became an indicator of democracy in individual systems and contributed to the stability and security in Europe. As a special autonomous field of public law it forms the basis of the social system and the system of government in all modern European states. The re-established principle of subsidiarity, which led to the decentralisation of public issues to the most appropriate level, plays a decisive role in this process. The focus of attention is the citizen equipped with modern rights, freedoms and new needs. The principle of subsidiarity constantly seeks the balance between the freedom of an individual and various authorities. Moreover, the principle of subsidiarity means that the state and international institutions, especially the EU, respect the role and position of local and regional authorities in a state. In accordance with the international law, the principle of subsidiarity is the fundamental principle in the European integration process."

A comparative glance at regional self-government in Europe shows that on the one hand, there are many countries dealing with similar issues, and on the other hand, there is a wide variety of institutional practice and solutions to these issues, all due to different national frameworks, circumstances, and politics.

The areas of regional self-government which are common to all CE member states are:

- the establishment of regional communities and/or changing of regional borders,

- the sharing of jurisdiction between various institutional and administrative levels of the state, and the transfer of new legislative and executive powers onto regions,

- the financing of regions,

- participation between regional authorities and communities,

- the representation of regional authorities at the level of the state and at a European level,

- and the fact that each member state uses unique, innovative approaches to solve these issues. ${ }^{\mathbf{2}}$

11 "Before proposing legislative acts, the Commission shall consult widely. Such consultations shall, where appropriate, take in account the regional and local dimension of the action envisaged. In cases of exceptional urgency, the Commission shall not conduct such consultations. It shall give reasons for its decision in its proposals. " Protocol on the application of the principles of subsidiarity and proportionality, Treaty of Lisbon, C 306/150, Article 2.

12 Declaration on regional self-government, Valencia Declaration, pp. 8, 9. 


\section{Stane Vlaj \\ Regionalisation of the Republic of Slovenia}

The regional level is gaining importance in numerous countries as the level for political decision making and management. This is evident from the following: the transfer of more and more authority to regions, the inclusion of regional (and local) communities into decision making regarding the EU politics, and the identification of the regional dimension as a territorial level on which increasingly more complicated problems in today's economic, social and political contexts can be addressed.

The models of local self-government vary in volume, structure, tasks and their relations to the state. Their common feature is that they each rest on their own tradition and historical development. Different models of local selfgovernment will continue to exist in the future, for there does not and cannot exist a single model, not even within individual (federal) states.

In Europe we can identify the following six models of regionalisation:

- regions with the power to enact primary legislation the existence of which is

- guaranteed by the Constitution / by a federal Agreement and cannot be questioned against their will,

- regions with the power to enact primary legislation the existence of which is not guaranteed by the Constitution / by a federal Agreement,

- regions with the power to enact legislation according to the framework (principles, general provisions) established by national legislation the existence of which is guaranteed by the Constitution,

- regions with the power to adopt laws and/or other regional legislative acts according to the framework (principles, general provisions) established by national legislation the existence of which is not guaranteed by the Constitution,

- regions with decision-making power (without legislative power) and councils directly elected by the population, ${ }^{\mathbf{1 3}}$

- regions with decision-making power (without legislative power) and councils elected by the component local authorities.

It should be underlined that these models do not exhaustively cover the full reality of regional self-government in Europe because they are based on a "photograph" of only a limited number of States. Thus the situation in other countries may not be (fully) covered, and what's more, within some of the States examined in depth significant changes to the system have meanwhile

13 This is the model of the regionalisation of the Republic of Slovenia, too. 
been introduced. ${ }^{\mathbf{1 4}}$ The models may therefore be considered as a valuable source of information and inspiration, but not as an exhaustive inventory and categorisation of the arrangements for regional self-government that exist in Europe.

When Romania and Bulgaria became members of the EU, the number of local, regional and federated governments in Europe jumped to 91,252. Decentralisation, regionalisation and territorial reorganisation have continued over these past years in a good number of countries. ${ }^{15}$ The EU consists of $27 \mathrm{Mem}$ ber States, three of which have a federal structure (Germany, Austria and Belgium). Sub-national authorities are divided into one, two or three levels depending on the country. The first level which corresponds to the municipal level ${ }^{\mathbf{1 6}}$ gives over 91,252 authorities, $80 \%$ of them are located in only five countries: France (40\% of European municipalities), Germany, Spain, Italy, and the Czech Republic. The second level (1,150 authorities) corresponds to the intermediate level in large countries such as Spain, France and Poland, but is the largest geographical level in certain smaller countries (Greece, Hungary, Sweden etc). In Austria, the second level corresponds to the federated States. The third level gives 104 diverse authorities: regions in the large unitary States (France and Poland), federated states in the countries with a federal structure (Germany and Belgium), and regions with a high degree of autonomy and legislative power in certain unitary States whose organisation increasingly resembles a federal structure (Spain, Italy, United Kingdom). ${ }^{\mathbf{7}}$

The territorial reform in Denmark is very interesting. In June 2005, Denmark adopted a structural reform of its territorial organisation aimed at making sub-national governments better at managing their public services. The reform,

14 Final activity report of the Steering committee on local and regional democracy (CDLR) to the Committee of

Ministers on the completion of the groundwork for the elaboration of a legal instrument on regional self-government. CDLR, 7 January 2002. PART C: OUTLINES, SYNTHESES AND OVERVIEWS OF SIX MODELS OF REGIONAL SELF-GOVERNMENT, pp. 3, 28, 39, 49, 57.

15 Sub-national public finance in the European Union, DEXIA, Paris, December 2007, p. 1. "Economic Outlook 2007- Sub-national public finance in the European Union": this annual Economic Outlook portrays the institutional and financial situation of the sub-national public sector in the 27 Member States of the EU between 2000 and 2006.

16 In more than half of the EU countries, the municipal level includes several subcategories. A distinction is often made between urban and rural municipalities (Cyprus, Estonia, Greece and Romania) but also within urban municipalities. Certain cities with greater demographic, administrative or socio-economic importance are given special status and thus additional competences (cities with county status in Hungary and Poland, republican cities in Latvia, etc.). Certain countries with large municipalities have an intramunicipal level that is responsible for providing local public services. Ibid., p. 6 .

17 lbid., p. 6. 


\section{Stane Vlaj \\ Regionalisation of the Republic of Slovenia}

which went into effect on 1 January 2007, brought about three major changes at the territorial level. The number of municipalities was reduced from 271 to 98 through a series of mergers. ${ }^{\mathbf{1 8}}$ The average population of Danish municipalities jumped from 20,000 to approximately 55,000 inhabitants. The 13 counties were replaced by 5 regions, each with between 0.6 to 1.6 million inhabitants. The counties' competences were spread between the regions, the municipalities and the central State. The new regions took over responsibility for health care $(95 \%$ of their current expenditure). Municipal competences were bolstered, most notably in the areas of education, social services, environmental protection, town and country planning, and transportation. Hence, municipalities became responsible for most of the public services to the population. From the counties, the central government inherited responsibility for secondary education. A new financing system has been put in place along with the territorial reform. ${ }^{\mathbf{1 9}}$

New regions are not permitted to levy taxes and are mostly financed by State grants and municipal subsidies. The municipalities have inherited the lion's share of taxes from the former counties. The tax brackets of the two main local taxes (the local income tax and the property tax on land) have been increased. Most of the shared tax has been abolished. Only the corporate income tax is still shared between the State and the municipalities. Moreover, a new system of tax equalisation has been put in place for the municipalities.

In 2006, sub-national public sector expenditure grew by $2.3 \%$ in volume to reach 1,825 bilion euros $-15.7 \%$ of the European GDP and $33.6 \%$ of total public expenditure. The most remarkable increase was witnessed in investment $(+6.6 \%)$, mostly stimulated by the new 12 EU member states. Totalling nearly 200 bilion euros, sub-national public sector investment accounted for more than two thirds of total public investment. ${ }^{20}$

The importance of the sub-national public sector in the overall economy varies considerably from country to country, the expenditure/GDP ratio ranging from $0.6 \%$ in Malta to $33.4 \%$ in Denmark. The weight depends notably on the breadth and type of competences sub-national entities carry out. The economic

18 Before the end of the reform process in 2009, the number of local authorities in Latvia should drop from 527 to just 105. Only a few countries are heading in the other direction and look to add to their number of municipalities. In Slovenia, the number of municipalities has grown from 147 in 1993 to 210 in 2006, mostly because the finance structure favours smaller municipalities.

19 lbid., p. 7.

20 lbid, pp. 1, 8-14. 
weight of the sub-national public sector is particularly heavy in highly decentralised countries such as the Scandinavian countries (over 25\% of GDP in Sweden and Denmark), countries with a federal structure and the regionalised States (Spain and Italy). The importance of the sub-national public sector in the economy can also be analysed in terms of its weight in total public spending.

The amounts of expenditures devoted to operating and capital expenditures by the level of sub-national government in 2005 in Slovenia (in million euro): operating expenditures - 855,65; capital expenditures - 516,43: total expenditures $-1.372,08 .^{21}$

Table 2: The breakdown of sub-national revenues in 2005 by type of resources and level of sub-national government (in million euro)

\begin{tabular}{|c|c|c|c|c|c|c|}
\hline & $\begin{array}{l}1^{\text {st }} \\
\text { level }\end{array}$ & $\begin{array}{c}2^{\text {nd }} \\
\text { level }\end{array}$ & $\begin{array}{l}3 r^{d} \\
\text { level }\end{array}$ & $\begin{array}{l}\text { Federated } \\
\text { States }\end{array}$ & $\begin{array}{c}\text { Total } \\
\text { sub-national } \\
\text { government }\end{array}$ & $\begin{array}{l}\text { Total conso- } \\
\text { lidated }\end{array}$ \\
\hline TAX REVENUES & 825,04 & $\ldots$ & $\ldots$ & $\ldots$ & 825,04 & 825,04 \\
\hline $\begin{array}{l}\text { - of which own source } \\
\text { tax revenues }\end{array}$ & 248,34 & $\ldots$ & $\ldots$ & $\ldots$ & 248,34 & 248,34 \\
\hline $\begin{array}{l}\text { - of which shared } \\
\text { tax revenues }\end{array}$ & 576,70 & $\ldots$ & $\cdots$ & $\cdots$ & 576,70 & 576,70 \\
\hline GRANTS & 292,85 & $\ldots$ & $\ldots$ & $\ldots$ & 292,85 & 292,85 \\
\hline $\begin{array}{l}\text { - of which earmarked } \\
\text { grants }\end{array}$ & /. & $\cdots$ & $\cdots$ & $\ldots$ & /. & /. \\
\hline - of which general grants & l & $\cdots$ & $\ldots$ & $\cdots$ & l & l \\
\hline OTHER REVENUES & 307,05 & $\cdots$ & $\ldots$ & $\cdots$ & 307,05 & 307,05 \\
\hline - of which assets sales & 104,29 & $\ldots$ & $\ldots$ & $\ldots$ & 104,29 & 104,29 \\
\hline - of which fees & 0 & $\ldots$ & $\ldots$ & $\ldots$ & 0 & 0 \\
\hline TOTAL & $1.424,94$ & $\ldots$ & $\ldots$ & $\ldots$ & $1.424,94$ & $1.424,94$ \\
\hline
\end{tabular}

Sources of information: Bulletin of public finance January/2007

21 Source : http://www.fu.uni-lj.si/sib/vhod.html 


\section{Stane Vlaj}

\section{Regionalisation of the Republic of Slovenia}

The operating transfers for local public services and transfers to individuals (entitlements) amount to 528,34 million euros. The main expenditure of local budget goes to child care, the support of economic affairs which include tourism and agriculture, spatial and housing policy expenditure, and to cultural and sport support at the local level. The main significant impact on the subnational operating expenditures over the past few years was generated through new regulations which transferred new responsibilities to the local level. The new regulations imposed new policy objectives on environment protection, social and child care, and tax obligations.

The main capital expenditure is located in transport infrastructure, waste and water infrastructure, refuse deposists, schools, kindergartens, sport, housing and social facilities.

\section{Introduction of regions in Slovenia}

The adopted constitutional amendments concerning local self-government will enable Slovenia to get a two-level self-government - after years of professional and political debates - the type of which already strongly prevails in most European countries. Currently Slovenia is one of the most centralised countries in Europe. Local self-government is under strong auspices of the State in terms of content and finance. Regions as a mandatory second level of selfgovernment will be of major importance for the decentralisation of Slovenia, and consequently for the implementation of the principle of subsidiarity as the fundamental principle arranging relations between the State and sub-national government levels. From the system point of view, regions as the new administrative-territorial unit will bring a number of changes to other parts of the system, i.e. the legal order or legislation, public finances, state administration, the position of municipalities, the field of work of individual ministries, the cross-border cooperation of local communities, international relations and associations (the $\mathrm{CE}$, the $\mathrm{EU}$ and others), and the status of the citizens.

The importance of regions can be viewed from various points of view, e.g. constitutional, administrative and organisational, economic, geographical as well as internal political and international point of view. With the latter two, it is also a matter of a more efficient acquisition and use of funding from the EU Structural Funds as well as the inclusion of regions in the European regional cooperation which consists of cross-border, transnational and net cooperation, 


\section{Regionalisation of the Republic of Slovenia}

and is believed to promote a higher integration of the territory of the Union. The adequacy of the representation of the Slovenian self-government in the CE (the Congress of Local and Regional Authorities of the CE, the Parliamentary Assembly of the CE, the Committees of the $\mathrm{CE}$ ) and in other international associations (e.g. the Committee of the Regions in the EU) will also be improved.

The constitutional amendments on local government, which were proposed by expert advisers, were adopted by the National Assembly at its session on 27 June 2006. The National Assembly adopted three constitutional amendments: a new Article $143^{\mathbf{2 2}}$ and amendments to Articles 121 and $140 .^{\mathbf{2 3}}$ The amendment to Article 121 ought to make it possible for tasks of state administration to be conducted by other administrative bodies (e.g. administrative districts) and bodies of local communities in addition to ministries, which would enable the dispersion and decentralisation of state administration and the implementation of the European principle of subsidiarity (together with the proposed amendment to Article 140 and with Article 143), as well as a more suitable regulation of the institution of public authority. The amendment to Article 140 would make it possible for the state to transfer the administration of individual tasks to the local communities from state jurisdiction by an act without their prior consent, provided the state also ensures the funding. This would enable the execution of state tasks in the local communities and the implementation of the principle of subsidiarity.

The Constitution of the Republic of Slovenia with the adopted Amandments clearly declared that Slovenia has two levels of local self-government -

22 Article 143

"(region)"

"A region is a local self-governing community that carries out local affairs of broader significance and affairs of regional significance as defined by law. Regions are established by an act that also defines their territory, seat, and name. The act is adopted by the National Assembly by a two-thirds majority of votes of MPs present. The process for adopting the act must ensure the participation of the municipalities. With the act the state transfers the administration of individual tasks to the regions from state jurisdiction, and it must ensure them the necessary funding for this."

23 In Article 121 the title of the article is changed to read:

- "(public authority)"

- Paragraph one is struck out.

Paragraph two is changed to read:

- $\quad$ "Legal entities and natural persons may receive public authority to conduct particular tasks of state administration by the act or on the basis of it."

In Article 140 paragraph two is changed to read:

- $\quad$ "The state may transfer the administration of individual tasks to the municipalities from state jurisdiction by the act if it also ensures the necessary funding for this." 


\section{Stane Vlaj}

\section{Regionalisation of the Republic of Slovenia}

municipalities as the basic self-government local communities and regions ${ }^{\mathbf{2 4}}$ as wider local communities.

The adopted constitutional provisions are the basis for drawing up laws which will enable the decentralisation of powers and the transfer of an important part of public matters from the state to the regional level. The legislation should define the regions as an intermediate level of local self-government between the state and municipalities, as territorial communities with the status of a legal entity, with their own property and financial resources, with original competences and a directly elected representative body, and as territorial units responsible for carrying out the first level of state administration. The Act on Regions, the Act on the Transfer of Compentences, the Act on the Establishment of Regions, the Regional Elections Act and the Financing of Regions Act will show how stable the political consensus achieved upon the adoption of the constitutional amendments is.

Along with the introduction of regions, the available property for the implementation of their tasks should be clearly defined. Without a clear supervision of property, regulations for its administration and regulated competences in administration of this property, regional bodies will not have the proper tools to take efficient measures. The administration of public property is the foundation in securing public services and obtaining additional financial resources. Fiscal resources; both primary, which are determined by the local level itself, as well as the ones delegated from the state level, represent the basic drive in the implementation of regional tasks. If these resources are not sufficient due to unequal development of individual areas, the state should intervene with a financial equalisation.

\subsection{The size and number of regions in the Republic of Slovenia}

An appropriate division of the state territory into regions is the basis for the optimal territorial organisation of material activities as well as for the settlement of population and decentralisation of state functions. Numerous economic, administrative, geographical and other reasons justify the need to divide Slovenia into regions despite the small size of its territory. The selection of diverse possibilities for the division of Slovenia into regions presented by

24 Our regions fall into a lower level of NUTS3 according to the statistical classification of the EU as well as the Slovenian Standard Classification of Territorial Units (SKTE). 
various authors in The Regions in Slovenia (Pokrajine $v$ Sloveniji, 1999) points to the possibility of applying various professional principles and criteria to regionalisation resulting ining several different numbers of regions.

Studies have shown that the optimal number would be eight. The project expert group most often mentioned the division of Slovenia into eight regions as the most appropriate solution in several aspects. This solution has also gainned most support in wider professional circles. The proposed regions and their centres are (these are working names for regions): the Pomurje region Murska Sobota; the Podravje region - Maribor; the Savinjska region - Celje; the Dolenjska (or the Southeast) region - Novo mesto; the Central region - Ljubljana; the Gorenjska region - Kranj; the North Littoral (or the Goriška) region Nova Gorica; the South Littoral (or the Littoral-Karst) region - Koper.

In view of Slovenia's geographical, settlement and economic structure, present European regionalisation tendencies and the envisaged scope of tasks to be performed by regions, the division into eight regions would, in the opinion of the majority of experts, enable a more cost-effective and optimal realisation of the demanding autonomous tasks and duties. The national development programmes define the proposed centres of regions (Murska Sobota, Maribor, Celje, Novo mesto, Ljubljana, Kranj, Nova Gorica and Koper) as the epicentres of regional development.

However, there are also other models of possible division with their advantages and disadvantages. It should be stressed that the criteria of geographical diversity and the inhabitants' feeling of belonging to a certain region lead to the division into a greater number of regions (more than 10) while the developmental, national, strategic and the anticipated globalisation challenges lead to the division into a smaller number of regions (less than 10).

As is known, the Government of the Republic of Slovenia is proposing the establishment of fourteen regions in Slovenia. ${ }^{\mathbf{2 5}}$

It holds the opinion that "the regionalization of Slovenia into fourteen regions is the most appropriate basis for public debate and discourse in municipal councils. The proposition is based on previous suggestions regarding the tasks and responsibilities of regions, the proposed system of financing, as well as factors relating to population, economy, and history.

25 The proposed regions are: the Celjska region, the Dolenjsko-belokranjska region, the Gorenjska region, the Kamniško-zasavska region, the Koroška region, the Notranjska region, the Ljubljanska region, the Pomursko-prleška region, the Posavska region, the Istrsko-kraška region, the Savinjsko-šaleška region, the Goriška region, the Štajerska region, and the Ptujsko-ormoška region. 


\section{Stane Vlaj \\ Regionalisation of the Republic of Slovenia}

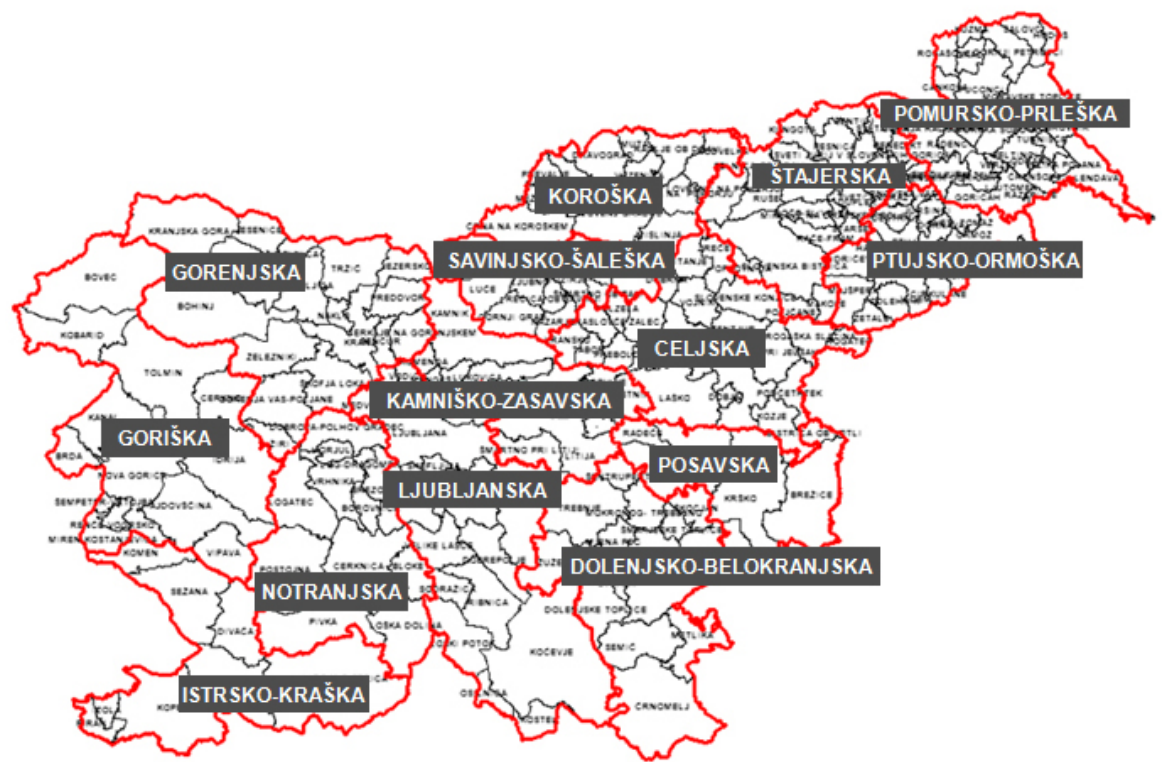

Source: Government Office for Local Self-Government and Regional Policy, February 2008

It takes into account the division of Slovenia into developmental regions and the contemporary territorialization of national administration. "Historical reasons ${ }^{\mathbf{2 6}}$ are also mentioned alongside the will of the people. ${ }^{\mathbf{2 7}}$ Experts, however, (since 2004) generally agree that economic, social, geographical, comparative, cross-border, national, European, and global factors all point to the implementation of $6^{\mathbf{2 8}}$ up to a maximum of 8 regions ${ }^{\mathbf{2 9}}$ as being more appropriate. Thus experts are in favour of a model involving large regions with enough human and material resources to carry out their (rather extensive) tasks, regions that would be a fairly strong partner in relation to the state, regions that

26 Attention must be called here to the fact that regionalisation represents an entirely new form of autonomous local community, which we have never had in Slovenia and therefore has no earlier tradition. Stane Vlaj, Lokalna samouprava: teorija in praksa, Fakulteta za upravo, Ljubljana, 2006, p. 259.

27 This was never determined, as the constitution does not prescribe the need for a referendum on regions like it does with municipalities (Article 139).

28 These being the Podravska or the Northeast region, the Savinjska region, the Southeast or the Dolenjska region, the Osrednjeslovenska region, the Gorenjska region, and the Primorska region. Dušan Plut, In: Stane Vlaj, Lokalna samouprava: teorija in praksa, Fakulteta za upravo, Ljubljana 2006, pp. 267, 277.

29 "The regions with suggested regional centres are to be (working names for regions): Pomurska region - Murska Sobota; Podravska region - Maribor; Savinjska region - Celje; Dolenjska region (also might be called the South-east region) - Novo mesto; Osrednjeslovenska region - Ljubljana; Gorenjska region - Kranj; Severna Primorska region (or Goriška region) - Nova Gorica; Južna Primorska region (or Obalnokraška region) - Koper.» Dušan Plut, ibid. 


\section{Regionalisation of the Republic of Slovenia}

would be more important for cross-border issues, and regions that would be more effective in gaining access to the EU funds. Also, such regions would be more economic and generally more effective than smaller regions. The number of six to eight regions is the result if we consider that each region should have at least 100,000 inhabitants, and should fulfill a number of other criteria - the geographical structure of the territory, material and other factors needed for successful economic, social and cultural development etc. ${ }^{\mathbf{3 0}}$

It should be noted that large regions have more competences and vice versa. In view of the envisaged wide scope of the competences and tasks of future regions, the division into fourteen regions (the concept of the socalled development regions) raises justified doubts as to whether the administrative and other, particularly development and service tasks, could be performed well.

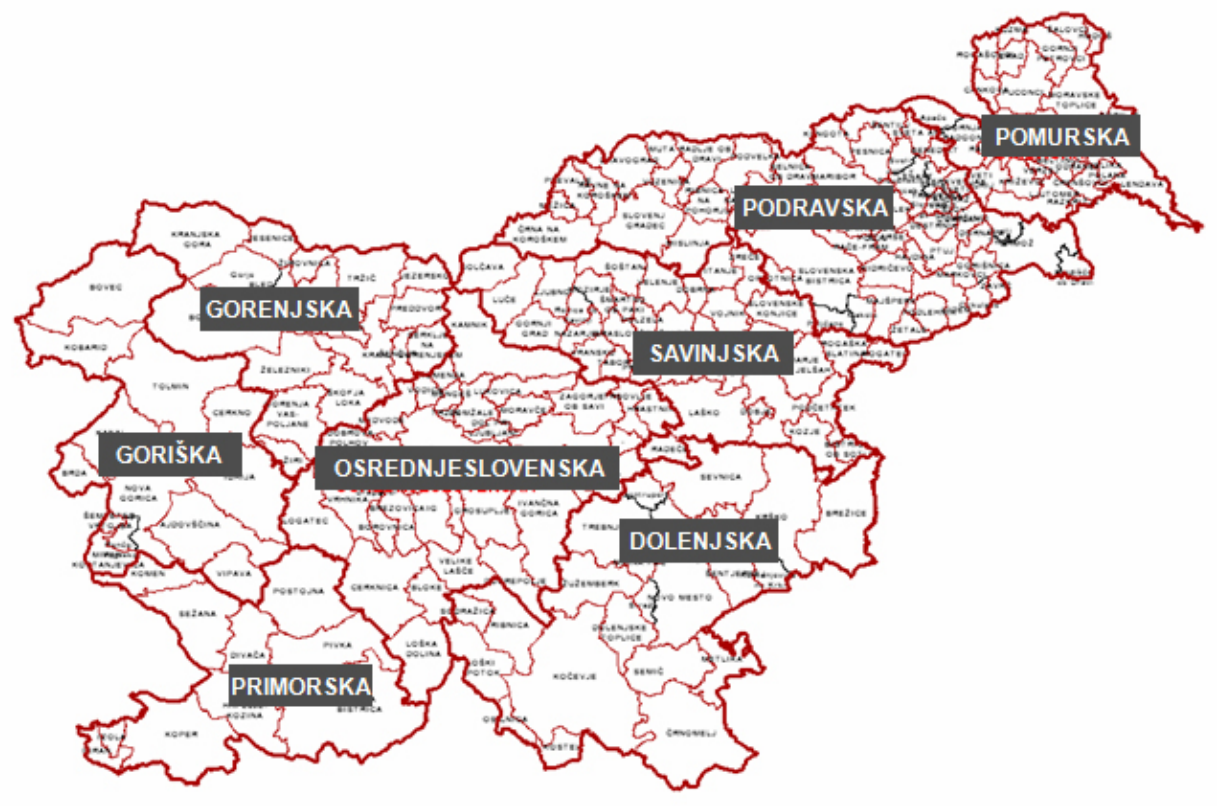

Source: Government Office for Local Self-Government and Regional Policy, Ljubljana, 2004

30 "Judging by the structure of Slovenia according to geography, population, and economy, modern European drives for regionalization and the tasks that would be faced by regions, the division into 8 regions, according to most experts, would make the most sense as it would enable the best balance between efficiency and cost, and would optimally fulfill the needs of autonomy. " Dušan Plut, Načela, kriteriji in regionalizacija Slovenije z vidika členitve na pokrajine, Pokrajina - druga raven lokalne samouprave, Inštitut za lokalno samoupravo pri Fakulteti za upravo, Ljubljana, junij 2004, p. 27. 


\section{Stane Vlaj \\ Regionalisation of the Republic of Slovenia}

Here it is important to point out the international standards, criteria, and directives. The conference of the European ministers responsible for local and regional self-government, which took place in February 2005 in Budapest ${ }^{\mathbf{3 1}}$, emphasised in their closing declaration that "ensuring good local and regional governance is an essential goal to strive towards for all member states, in order to answer the challenges faced by our societies and in order to become closer to the legitimate expectations of our citizens. " ${ }^{\mathbf{3 2}}$ One of the challenges is to fully emphasise the principle of subsidiarity by defining through law accountability, structure, and the boundaries of local and regional communities. Another challenge is the fostering of effective relations between various levels of territorial administration, particularly between central and local authorities. For these, and for other challenges, different activities and solutions are prescribed by the Budapest Agenda. For example, as far as regional selfgovernment is concerned, its development should be followed in individual states, so as to compare and share the innovations (and possible complications) discovered by individual member states in dealing with the issues common to all. The conference also stressed that in the search for answers to the questions that arise from regional self-government and other issues dealt with by the Agenda ${ }^{33}$, ECLS should be used, along with all other documents of the Council - in short, consulting all existing and accepted acquis of the CE on good local and regional governance is a must. Thus ECLS promotes the establishment of local communities capable of operating in a legal framework, and so dealing with a substantial part of the public issues on their own and to the benefit of the local population (Article 3).

We can list a few specific examples regarding the size of regions. All states aim to determine such a size of local and regional communities that would be large enough to allow for enough financial and human resources to provide public services of a sufficiently high standard for its inhabitants. ${ }^{\mathbf{3 4}}$ The

31 14th Session, 24-25 February 2005, Budapest. The Agenda deals with four groups of challenges: the legal framework and institutional structure, democratic participation and public ethics, local and regional finances, and public service jobs, as well as cross-border and inter-territorial cooperation.

32 European Committee on Local and Regional Democracy (CDLR), Overview of the activities for the CDLR to implement the Budapest Agenda for delivering good local and regional government, Phase 2005-2007, Version updated for the CDLR meeting 3. 5 December 2007, Strasbourg, 14 November 2007, p. 3.

33 European Committee on Local and Regional Democracy (CDLR), Programme of activities 2008-2009, Appendix II, Agenda for delivering good local and regional governance, pp. 47-52.

34 The parameters that must be taken into account when forming new territorial communities are as follows: size (of territory and population), function (aims and accountability), autonomy (relations between state government and local/regional self-government, fiscal 
importance of the territory is obvious whether we look at it from an economic, a social, political, or an administrative point of view. In Italy, which has over 57 million inhabitants, there are 103 provinces (units comparable to the regions discussed here), and each province must have at least 200,000 inhabitants, aside from fulfilling other criteria. ${ }^{\mathbf{3 5}}$ Denmark, a country with a little over 5 million inhabitants, once had 14 counties. These have now been reformed as five regions, and the number of municipalities has been halved. A municipality must have at least 20,000 inhabitants, or form a mandatory association with other municipalities. ${ }^{36}$

\subsection{Competences and financing of regions in Slovenia}

The region will be responsible for the implementation of: a) tasks of local importance; b) tasks of regional importance and c) tasks of state importance.

Tasks of general local importance are the region's primary tasks and will be carried out by regions independently as their proper tasks within their constitutional autonomy, but as a rule with a suitable participation of municipalities (e.g. promotion of economic development; promotion of marine fishing; prevention of drug abuse). The tasks of regional importance, which will be delegated to the competence of regions by way of law, will also be the primary tasks of the region. These are the tasks that are neither of local nor state importance (e.g. promotion of a balanced regional development, construction and maintenance of regional roads, matters of spatial planning, regional traffic routes, establishment and maintenance of institutions of regional importance such as regional hospitals, regional education, cultural and social institutions etc).

Proper (primary) competences of regional authorities are the essential principle of self-government. The extent of these competences is one of the indicators of the level of regional self-government. The third kind of tasks would be the so-called delegated tasks. These are the tasks that regions are to carry out for the state (state administration tasks - e.g. issuing of building permits). The region would carry out the administrative tasks of the state, ex-

and functional interdependency), and methods of realisation (relations between public and private production). These parameters are mutually interdependent. Scandinavian countries emphasise that aside from financial reasons for reform that would result in more effective local and regional communities, the strengthening of democracy is also very important.

35 Law on local authority from 1991.

36 Council of Europe, Local and regional democracy in Denmark - CG (12) 8 Part II, Explanatory memorandum. 


\section{Stane Vlaj \\ Regionalisation of the Republic of Slovenia}

cept for administrative tasks which by way of law are performed directly by ministries and administrative tasks which by way of law are vested in the competence of municipalities.

The fundamental aim of creating regions in Slovenia is the decentralisation of governmental functions and the transfer of administrating important public duties and public finances from the level of the state to the level of the region. The region would thus administer local issues that have a wider importance, issues the scope of which reaches beyond municipalities, issues of regional importance decided on by the state as it transfers them to the region; aside from this, regions would also be in charge of national administrative duties when required by the state (and funded thereby). Tasks of a regional nature are generally those in the fields of spatial planning, harmonised regional development, environmental protection, traffic and transportation links, as well as specific activities in the public sector that have regional importance (regional hospitals, museums, theatres, archives etc).

The tasks of regions should generally and according to the administrative area be described in the law on regions, whereas specifically they should be determined in the law on regional responsibility; all of which involves changes in or additions to over fifty already existing laws. With the changes in the existing laws certain tasks will be transferred from the state's agencies, and with the additions, certain tasks will be reascribed to the appropriate level.

Taking over, and later carrying out, the tasks thus transferred to the regions is a process that could be hindered or prevented by:

- difficulties related to legal, technical, financial and staff-related transfers to the regional level,

- difficulties that arise from too large a number of (too small) regions,

- conceptual ambiguities regarding the separation of authority between self-governing regions and state agencies in the field. ${ }^{\mathbf{3 7}}$

For carrying out its duties, local self-government requires an adequate material basis that ensures its independence and impartiality. Financial independence is a prerequisite for true local self-government. In the opposite case, the right to administer its own duties - the entire point of local self-government becomes simply a formality, and local communities (in Slovenia's case municipalities and regions) actually become subservient to the state. Funds for their

37 Janez Šmidovnik, Problematika pokrajine kot nosilca javne uprave, XIV. Dnevi slovenske uprave, Portorož, September 2007, p. 2. 
operation are mainly their own finances, as local communities have the right to levy local taxes, as well as grants from the state. The state has to determine such a system of financing that the local authorities have as much freedom and independence regarding the usage of their funds for carrying out local tasks as possible.

According to Article 142 of the Constitution, a municipality - and thus mutatis mutandis a region - is financed by its own means, and only those municipalities unable to carry out their tasks by themselves due to their weaker economic status are to be financed by the state in accordance with the law. The principle of self-financing is thus a fundamental principle of financing municipalities (and regions), and laws passed according to the Constitution must adhere to it. Other constitutional articles deal with financing local selfgovernment as well. Thus Article 146 determines that the state and local communities acquire funds for realising their tasks by taxation and other mandatory flows of income, as well as by income from their assets, and Article 147 determines that the state, via laws, levies taxes, customs duties and other duties, whereas local communities levy taxes and other duties according to the criteria set out by the Constitution and the law. The fundamental principles of financing local communities are also determined by the ECLS (Article 9). ${ }^{\mathbf{3 8}}$ These principles are:

- the principle of appropriateness, according to which local communities are entitled to appropriate funds of their own within the framework of national economic policies

- the principle of proportionality, according to which the sources of financing local communities must be proportional to the scope of the tasks they carry out,

- the principle of self-financing, according to which at least part of the sources of financing local communities are made up of their own taxes and other duties, the amount of which the communities determine themselves within the framework of the law,

- the principle of flexibility, according to which the financial system should be diverse and adaptable enough to the fluctuation in expenses borne by local communities in carrying out their tasks,

- the principle of solidarity, according to which financially weaker local communities are to be aided by funds from the national budget,

38 Law on ratification of the European Charter on Local Self-Government (MELLS) (Official Gazette RS, No. 57/1996). 


\section{Stane Vlaj}

\section{Regionalisation of the Republic of Slovenia}

- the principle of consultation, according to which the opinion of local communities regarding the financing thereof must be acquired in an appropriate manner,

- the principle of independence, according to which funding from the state is not to be given with a specific purpose in mind, since local communities themselves should have as much freedom as possible when deciding how to use these funds,

- and the principle of incurring debts, according to which local communities are to have access to the domestic capital market for larger investments.

Some of these principles are not fulfilled in Slovenia as far as municipalities are concerned, as was determined by the Constitutional Court of the Republic of Slovenia ${ }^{\mathbf{3 9}}$, nor will they be fulfilled as far as regions are concerned. The Constitutional Court discovered that "the first sentence of Article 142 of the constitution, according to which municipalities finance themselves from their own resources, represents a rule that the legislative branch must take into account when drawing up a system of how to finance them. It is the municipality's responsibility to carry out local self-government. Because of this, the legislative branch must directly and primarily ensure that the municipalities have enough sources to finance themselves. Allocated sources are not sources created by the municipality itself, and therefore cannot be considered as the municipality's own financial sources. A system based on such sources creates an imbalance by making the municipality dependent on funds from the national budget, which is not in accordance with the demand for financial autonomy, as described in Article 142 of the constitution, nor the demand for functional autonomy of municipality, as described in Article 140 of the constitution." The law on financing regions has the same problems as the law on financing municipalities.

The system of financing lower levels of governance is determined by states via fiscal decentralisation, which determines appropriate sources of

39 U-I-24/07. "Articles 8, 11, 14, 23 and 38 of the Law on financing municipalities (Official Gazette RS, No. 123/06) are incompatible with the Constitution. Articles 12, 13, 21 and 24 of the Law on financing municipalities are compatible with the Constitution. The parliament must amend the aforementioned incompatibilites within one year after the publishing of this statement in the Official Gazette of the Republic of Slovenia." 
finance for lower levels of governance so they can carry out their purpose. ${ }^{\mathbf{4 0}}$ Due to the variation in regulating regional units, the systems of fiscal decentralisation also vary between states, so we cannot speak of a unified model of fiscal decentralisation. There are, however, common starting points for crafting models of financing sub-state levels of authority, which ensure that the goals of decentralisation are met. These rely on the allocation of fiscal sources in proportion to jurisdiction and on the autonomous use of these sources along with appropriate mechanisms of budgetary injections, and on supervision over how public funds are spent.

From a comparative overview of these implementations throughout the EU, we can see that in nearly all the states concerned regional levels have the option to levy their own taxes. It is only these sources that represent a true source of finance for lower levels of authority and lower levels of authority alone. These sourcesresult from the principle of fiscal federalism and are under complete control of the agencies at the regional level. They can also be adapted to the needs and possibilities in a given situation. The aim behind distributing tax sources is to motivate regional authorities to realise their potential, especially due to increasing needs in regional centres. ${ }^{\mathbf{4 1}}$

Only financially independent regions stimulated by fiscal autonomy can achieve the desired effect of encouraging development in society. The same holds true for our regions. In the case of centralised pre-distribution, which depends on the dispersal of public functions and on an administrative system that distributes fiscal sources from the state without real fiscal autonomy of the regions, one can hardly speak of any real effects of fiscal decentralisation.

40 "The theory on fiscal decentralization and debates on fiscal federalism assume the autonomy of lower levels of governance also in terms of levying their own taxes, with the possibility of affecting and/or determining the tax rate and/or base tax. In this way tax revenue can be adapted to local needs. On the other hand, autonomy with fiscal decentralization depends on the right and possibility of autonomous use of sources allocated to the local or regional authority in order for it to finance its basic tasks. "Vilma Milunovič, Fiskalna decentralizacija in financiranje pokrajin, XIV. Dnevi slovenske uprave, Portorož, September 2007, p. 3.

41 wIf the system of financing regions relies on the concept of developmental regions that are tied to their own potential for development, then each region should have the possibility of determining its own tax revenue to meet its developmental goals. Regions will be financially autonomous only then when regions will not have to rely on state subsidies and when they will have the possibility of levying their own taxes and thus complementing their sources of financing in a way that these adapt to the needs of covering costs in public service and the changing needs of development. Under these conditions, the maximum socioeconomic benefit of fiscal decentralization will be achieved. "Vilma Milunovič, ibid, p. 7. 


\section{Stane Vlaj}

\section{Regionalisation of the Republic of Slovenia}

\section{Conclusions}

Decentralisation, regionalisation and territorial reorganisation have continued over these past years in a good number of countries. In almost all CE member states, far-reaching reforms of regional authorities have been completed, are in progress or are planned for the years ahead. The majority of countries with a regional level of government have sought to increase its autonomy and competences.

The models of local self-government vary in volume, structure, tasks and their relations to the state. Their common feature is that they each rest on their own tradition and historical development. Different models of local selfgovernment will continue to exist in the future, for there does not and cannot exist a single model. The ECLS and other documents of the CE and the EU relating to local and regional communities respect the diversity of those models.

The member states of the CE recognise that recent trends in Europe towards increasing decentralisation and devolution of governmental institutions has in many states taken the form of introducing or strengthening regional selfgovernment. Regional self-government, where it exists, is part of democratic governance, and thus such regional authorities should be in conformity with democratic standards and principles and the principle of subsidiarity.

In Slovenia, local government should also be carried out at two levels, i.e. at the municipal and the regional one, just as it is in the large majority of European countries. After the establishment of regions, the decentralisation of the country will be directed at the regions. The region is a wider self-governing local community that conducts local affairs of wider significance and affairs of regional significance as defined by law. It will also conduct tasks of state administration in the space between the state and the municipality. Regions are established on areas that unite settlement, infrastructure and natural systems in uniform, complete spatial wholes, and in which it is possible to ensure equal opportunity for coordinated regional development and the implementation of the state's regional policy.

The introduction of regions will have numerous consequences for the other parts of the system, especially for the redistribution of power between the state, the regions, and municipalities, and for the new arrangement of financial and material issues between them.

In view of the envisaged wide scope of the competences and tasks of future regions, the division into fourteen regions (the concept of the so-called 
Stane Vlaj

\section{Regionalisation of the Republic of Slovenia}

development regions) raises justified doubts as to whether the administrative and other, particularly development and service tasks could be performed well.

Due to the absence of historical experience in establishing regions, we will have to rely on criteria such as the geographical features of the country, its traffic, economic, cultural and other connections, as well as the capabilities of each area to establish regions. The existent studies in Slovenia have shown that an optimal selection should bring about the formation of six to eight regions. There are also other models of regionalisation, which all have their strengths and weaknesses. It is often disregarded that large regions can have more competences and functions and vice versa.

Dr. Stane Vlaj, assistant professor at the Faculty of Public Administration in Ljubljana and director of its Institute of Local Self-Government, member of the Expert Group at the Constitutional Commission of the National Assembly of the Republic of Slovenia for the field of local self-government and alternate member from the Republic of Slovenia in the Group of Independent Expert on the European Charter of Local Self-Government at the Congress of Local and Regional Authorities of Europe (CLRAE) in Strasbourg. He is also member of the International Institute IFIMES. 


\section{Stane Vlaj \\ Regionalisation of the Republic of Slovenia}

\section{Bibliography}

- $\quad$ Act Ratifying the European Outline Convention of Transfrontier Cooperation between Authorities, Off. Gaz. RS, MP, no. 8/03.

- $\quad$ Act Ratifying the European Charter of Local Self-Government (MELLS), Off. Gaz. RS, No. 57/96.

- Constitutional Act amending Articles 121, 140. and 143 of the Constitution of the Republic of Slovenia (UZ 121, 140,143). Oficial Gazette of the Republic of Slovenia, 30. 6. 2006, no. 66/06.

- Activity report to the CDLR from the Drafting Committee for legal instrument on regional self-government, Part C: outlines, syntheses and overviews of six models of regional self-government, Strasbourg, 3. December 2001.

- Council of Europe, Steering Committee on Local and Regional Authorities (CDLR), Draft European Charter of Regional Self-Government, Strasbourg, 18 November 1997.

- Declaration of the Budapest Ministerial Conference on delivering good local and regional governance, 14th Session, Budapest, 24 - 25 February 2005.

- Draft Report on the current situation concerning regionalization and the prospects for developing regional self government in Council of Europe member states, Document prepared by Bernd Semmelroggen, The Congress of Local and Regional Authorities, Council of Europe, Strasbourg, 17 October 2006.

- EU subnational governments: an overview, 2007 Edition, CEMR-DEXIA, Paris, Dember 2007.

- Outline for preliminary draft report on the situation of regionalisation and the prospects for developing regional self-government in Council of Europe member States. The Congress of Local and Regional Authorities, Council of Europe. Strasbourg, 20 March 2006.

- Pokrajina : druga raven lokalne samouprave, (ur. S. VLAJ). Ljubljana: Inštitut za lokalno samoupravo pri Fakulteti za upravo, 2004.

- Posvet o regionalizaciji Slovenije, Fakulteta za upravo, Ljubljana, 22. junij 2006 (http://www.fu.uni-lj.si/ic/posvet_regionalizacija.asp).

- Protocol on the application of the principles of subsidiarity and proportionality, Treaty of Lisbon, C 306/150.

- Statistical Yearbook 2006, Territorial units and house numbers by municipalities and statistical region, detailed data, Slovenia, 31 December 2006.

- Subnational public finance in the European Union, Trends 2000/2006, DEXIA, Paris, December 2007. 
Stane Vlaj

\section{Regionalisation of the Republic of Slovenia}

- Šmidovnik, J (2008): Premajhne pokrajine ne morejo izvajati svojih pristojnosti, intervju, Objektiv (Dnevnik), sobota, 9. februarja 2008, str. $10-12$.

- Treaty of Lisbon amending the Treaty on European Union and the Treaty establishing the European Community, signed at Lisbon, 13 December 2007, Off. Journal of the EU, C 306, 17 December 2007.

- U-I-24/07 (Official Gazette RS, no. 123/06).

- Vlaj, S. (2008): Local Self-Government in the Republic of Slovenia - Current Situation and Perspective, Trends and Development of Public Administration in South East Europe, Faculty of Adminstration, Ljubljana, p. 46 - 61.

- Zakon o spodbujanju skladnega regionalnega razvoja, Ur. I. RS, št. 60/99, 56/03, 93/05 - prečiščeno besedilo. 
Stane Vlaj

Regionalisation of the Republic of Slovenia

\section{POVZETEK}

\section{REGIONALIZACIJA REPUBLIKE SLOVENIJE}

Avtor obravnava regionalizacijo Republike Slovenije, pri čemer vladne predloge pokrajinske zakonodaje sooča s strokovnimi merili, nameravano uvedbo pokrajin pa umešča tudi v evropska dogajanja na tem področju.

Po njegovem mnenju je temeljni cilj uvedbe pokrajin učinkovito in pregledno upravljanje za zagotavljanje kakovostnih storitev za lokalno in regionalno prebivalstvo. Gre za povezanost nove enote teritorialne samouprave $z$ vsebinskimi vprašanji, zlasti $z$ dobrim upravljanjem, ki bo $v$ korist tam živečega prebivalstva. $Z$ uvedbo in ustanovitvijo pokrajin se bo tudi $v$ naši ureditvi odprla pot za proces decentralizacije in uveljavljanje načela subsidiarnosti, ki ju obstoječa odsotnost vmesne ravni ne dopušča. Ustanovitev pokrajin je tudi eden ključnih korakov k uresničevanju skladnega regionalnega razvoja. Olajšale bodo tudi povezavo Slovenije z EU, še posebej glede uspešnejšega kandidiranja za sredstva EU iz strukturnih in kohezijskega sklada za spodbujanje skladnega regionalnega razvoja. Okrepile naj bi tudi čezmejno ozemeljsko sodelovanje lokalnih in regionalnih skupnosti.

Slovenija je zaenkrat ena najbolj centraliziranih držav v Evropi. Lokalna samouprava je vsebinsko in finančno pod odločilnim pokroviteljstvom države. Pokrajine kot obvezna druga raven lokalne samouprave bodo zelo pomembne za decentralizacijo Slovenije in s tem uresničevanje načela subsidiarnosti kot temeljnega načela za ureditev razmerij med državo in poddržavnimi ravnmi oblasti. S sistemskega vidika gledano bodo pokrajine kot nova upravnoteritorialna struktura prinesle številne spremembe $v$ ostalih delih družbenega sistema - pravnem redu oz. zakonodaji, javnih financah, državni upravi, položaju občin, delovnem področju posameznih ministrstev, čezmejnem sodelovanju lokalnih skupnosti, mednarodnih razmerjih in povezavah (SE, EU in drugih) ter seveda tudi v položaju državljanov.

Ustanovitev štirinajstih pokrajin je po večinskem strokovnem gledanju preveč. Določanje pokrajinskega območja mora izhajati najprej iz naravnih danosti ter skupnih potreb in interesov prebivalcev. Vse države si prizadevajo za takšno velikost lokalnih in regionalnih skupnosti, ki bo omogočala potrebne finančne in človeške vire za čim kakovostnejše javne storitve za zadovoljevanje sodobnih potreb prebivalcev. Pomembnost teritorija je 


\section{Regionalisation of the Republic of Slovenia}

povsem jasna, pa naj gre za gospodarski, socialni, politični ali upravni vidik.

Glede na geografsko, poselitveno in gospodarsko sestavo Slovenije, sodobne evropske regionalizacijske težnje in predvidene široke naloge pokrajine bi členitev na osem pokrajin po mnenju večine strokovnjakov omogočala glede na razmerje med učinkovitostjo in stroški najbolj smotrno, optimalno izpolnjevanje zahtevnih avtonomnih nalog in opravil. Predlog členitve na osem srednje velikih ( $z$ vidika Slovenije) pokrajin je po strokovnih kriterijih za geografsko, prebivalstveno, urbano in gospodarsko sestavo Slovenije ovrednoten kot najprimernejši. Členitev na štirinajst pokrajin (koncept t. i. razvojnih regij) z vidika predvidenih širokih pristojnosti in nalog pokrajin postavlja upravičen strokovni dvom o možnosti kakovostnega opravljanja upravnih in drugih, zlasti razvojnih in storitvenih funkcij. $Z$ vidika skladnejšega regionalnega razvoja pa je to (zgolj) ena od mogočih različic.

Regionalizem in krepitev regionalne samouprave sta $v$ središču procesa politične demokratizacije ter socialnega in gospodarskega razvoja $v$ večini držav članic SE. Regionalizacija je povezana z globalnimi, evropskimi in nacionalnimi političnimi procesi, ki države silijo $v$ reforme vseh temeljnih sestavin oblasti. Regionalizacija je del vseobsežnih političnih procesov $v$ državi in ne izoliran vidik teh reform.

Modeli lokalne samouprave se razlikujejo po obsegu, strukturi, zadevah in njihovih razmerjih do države. Njihova skupna značilnost je, da temeljijo na njihovi lastni tradiciji in zgodovinskem razvoju. Različni modeli lokalne samouprave bodo obstajali tudi $v$ prihodnje, ker ni in ne more biti enega modela, tudi znotraj posamezne (federalne) države ne.

Dobra lokalna in regionalna samouprava je javna dobrina, ki jo žele zagotoviti države članice SE. Za dobro upravljanje lokalnih in regionalnih skupnosti so izzivi in potrebne aktivnosti $v$ naslednjih letih te: demokratično državljanstvo in participacija na lokalni in regionalni ravni; pravni okvir in institucionalna struktura lokalne in regionalne samouprave; lokalne in regionalne finance; vodenje in upravljanje zmogljivosti lokalnih in regionalnih skupnosti; javna etika na lokalni in regionalni ravni; obmejno in čezmejno sodelovanje teritorialnih skupnosti ali oblasti.

Avtor je kritičen do nekaterih nekaterih pokrajinskih zakonov, ki so že v zakonodajnem postopku, neodvisna stroka pa pri njihovem oblikovanju ni sodelovala. Trmasto vztrajanje na 14 pokrajinah, katerih obseg, imena, sedeži pokrajinskih organov in uprave so se neprestano spreminjali, je 
povzročilo, da je bila celotna razprava osredotočena na ta vprašanja, veliko manj pa na koncept pokrajin, organizacijo pokrajinske uprave, pristojnosti in financiranje pokrajin, dobro upravljanje in še druga aktualna in odprta vprašanja.

Glede na široke zasnovane lokalne in regionalne naloge ter prenesene državne naloge na prihodnje pokrajine obstaja utemeljen dvom, da bi lahko bila npr. pokrajina z okoli 70000 ali še manj prebivalci kakovostno in finančno optimalna za prebivalke in prebivalce pokrajine, kar prinaša realno možnost zmanjšanja pristojnosti in vloge pokrajin, torej ohranjanje prevelike stopnje centralizacije, izrazito vlogo države in njenih izpostav uprave.

Posebej slab je predlog zakona o financiranju pokrajin. Brez urejenega sistema financiranja pa ne moremo govoriti o občinski in pokrajinski lokalni samoupravi. Finančni viri morajo biti v sorazmerju s pristojnostmi, ki jih lokalnim skupnostim določata ustava in zakon. Pri davkih obstaja v tujih ureditvah možnost predpisovanja lastnih davkov $v$ obliki samostojnih davčnih virov ali možnost predpisovanja dodatnih zneskov na že odmerjene davke ter delitev posameznih davčnih virov med državno in lokalno ravnijo. Načelo samofinanciranja namreč zahteva, da mora vsaj del finančnih virov lokalnih skupnosti izvirati iz lastnih davkov in drugih dajatev, katerih višino lokalne skupnosti v okviru zakona določajo same.

Avtor zagovarja stališče, da RS pokrajine vsekakor potrebuje, dvomi pa, da je po polomu predloga zakona o ustanovitvi pokrajin mogoče kaj napraviti oz. popraviti že $v$ tem mandatnem obdobju, kar je seveda velika škoda. Pri tem ne gre za to, katero od predlaganih pokrajin črtati, temveč za odločitev, ali Slovenija potrebuje velike in močne pokrajine ali pa razdrobitev na štirinajst. Če se Slovenija odloči za model velikih pokrajin, je treba temu primerno in ustrezno prilagoditi vso predlagano pokrajinsko zakonodajo. 